\title{
NEW OBSERVATIONS OF MEDDY MOVEMENT SOUTH OF THE TEJO PLATEAU
}

\author{
Walter Zenk, Kathy Schultz Tokos \\ and Olaf Boebel
}

Institut für Meereskunde an der Universität Kiel, Germany

\begin{abstract}
Mediterranean salt lenses (meddies) are a dominant factor in the salt budget of the Atlantic at middepth. In spite of their important role, their juvenile migration has not yet been directly observed. For the first time, two RAFOS float trajectories show strong evidence of a meddy along the Iberian continental slope off Lisbon. Over six weeks we obtained drift observations from two levels (629, $847 \mathrm{dbar}$ ). Both instruments recorded a series of loops with an azimuthal speed $\mathrm{O}\left(30 \mathrm{~cm} \mathrm{~s}^{-1}\right)$ at a radius of about $25 \mathrm{~km}$. Relatively high propagation speeds of several centimeters per second indicate the meddy was probably carried along with the undercurrent of Mediterranean Water. The Tejo Plateau, a prominent feature of the continental slope and a natural obstacle for the spreading Mediterranean Water tongue, appears to act as a deflector for advected meddies possibly formed by interaction of the undercurrent with the canyonrich topography farther south.
\end{abstract}

\section{Introduction}

There has been a growing interest in the spreading and mixing of the Mediterranean Water plume in the Northeast Atlantic during the last decade. Initial elements for this interest were the detection of warm and highly saline, mesoscale meddies in the western North Atlantic (McDowell and Rossby, 1978) and in the Canary Basin (Armi and Zenk, 1984). Meddies can be described as isolated, $1000 \mathrm{~m}$ deep rotating lenses of Gulf of Cadiz Water drifting out into the open Atlantic. They have been observed for several hundred days, migrating more than a thousand kilometers. Their hydrographic properties are similar to the outflow water found in the Gulf of Cadiz. Richardson et al. (1989) have estimated that about a quarter of the Mediterranean outflow enters the deep Atlantic as meddies. Possible generation processes and sites have been repeatedly discussed in the literature. In an earlier study, Käse and Zenk (1987) have proposed that the deep reaching Azores Current in the northern Canary Basin can cause the salt tongue to become baroclinically unstable and produce meddies. However, recent studies show meddies may be formed by topographic control in the Gulf of Cadiz and its canyons (Prater, 1992). Meddy separation from the undercurrent may also be triggered by outflow pulses (Nof, 1991). A pulse (duration 2d) was traced in data records as a solitary event propagating

Copyright 1992 by the American Geophysical Union.

Paper number 92GL02139

0094-8534/92/92GL-02139\$03.00 between the Strait of Gibraltar and $8^{\circ} 40^{\prime} \mathrm{W}$ (Gründlingh, 1981).

More recently it has been successfully demonstrated that some meddies can have a surface expression detectable by drifting surface buoys (Käse and Zenk, 1987), in infrared images, or in altimeter data from satellites. In one instance Stammer et al. (1991) have traced a meddy in altimeter data on its southwestward migration into the Iberian Basin over 16 months. Their hypothesis was verified by a moored current meter array which incidentally was hit by the migrating meddy.

Observations of meddy propagation, and possibly generation, can be achieved by neutrally buoyant in-situ drifters. In 1990 we started to use RAFOS floats for Mediterranean Water studies at Kiel. These instruments are launched from a ship and sink to a predetermined depth where they drift horizontally with internal ocean currents (Rossby et al., 1986; König and Zenk, 1992). RAFOS floats record arrival times of coded sound signals together with pressure $(p)$ and temperature $(T)$ information usually three times per day. Positions can be calculated with a minimum of two signals originating from moored sound sources, which are part of the RAFOS system. At the end of their missions, typically after several weeks or months, floats drop their ballast, return to the surface, and transmit their memory content via satellite link (Systeme ARGOS).

\section{The SONNE float experiment}

On November 15, 1991, two RAFOS floats (Nos. 20, 28) were launched from FS SONNE $120 \mathrm{~km}$ southwest of Lisbon. Their drop positions lay only $11 \mathrm{~km}$ apart. Both sites were chosen according to the geological objectives of the SONNE cruise and could not be arranged in accordance with our hydrographic interests. However, both drop sites lie within the well-known Mediterranean undercurrent west of Portugal. Most of the outflow parallels the Iberian Peninsula after it passes the gateway between Cape St. Vincent and the Gorringe Bank (Zenk and Armi, 1990). With the chosen ballast weights, we could expect both floats to mark the undercurrent, easily recognized in historical sections of temperature and salinity (cf. Madelain, 1976). Approaching the latitude of $38.5^{\circ} \mathrm{N}$, the Mediterranean Water flow has to diverge from the coastline because it encounters the topographical obstacle of the Tejo Plateau. As intended, both floats surfaced (S, in Figure 2) on January 1, 1992, after a mission length of 46 days. In spite of the close proximity of their launch positions (L), floats No. 20 and 28 returned to the surface at significantly different positions, $216 \mathrm{~km}$ apart. No. 20 appeared to have stayed in the launch region while No. 28 popped up on the northeastern flank of the Tejo 
Plateau. Distances $\overline{\mathrm{L}-\mathrm{S}}=29$ and $205 \mathrm{~km}$ were calculated for No. 20 and 28 , respectively.

The subsequent data analysis of the memory content of both floats revealed that two out of originally three moored sound sources had failed. Our floats heard only sound source $\mathrm{N}$ which is moored at $43^{\circ} \mathrm{N}, 15^{\circ} \mathrm{W}, 640 \mathrm{~km}$ northwest of Lisbon.

\section{Data retum}

Figure 1 displays temporal changes of float parameters $d$ (distance from $\mathrm{N}$ ), $p$, and $T$. The distance $d$ was calculated under the assumption of a constant speed of sound $\left(1.5 \mathrm{~km} \mathrm{~s}^{-1}\right)$. During the first 20 days, both floats show undulating progression towards $\mathrm{N}$. The subsequent trend in both time series differs. No. 20 continues undulating during the following 3 weeks, while No. 28 approaches a nearly constant distance of $485 \mathrm{~km}$ from N. Mean values and standard deviations of $p$ and $T$ amount $847 \pm 14 \mathrm{dbar}$ and $12.1 \pm 0.2^{\circ} \mathrm{C}$ for No. 20 , and $629 \pm 16 \mathrm{dbar}$ and $11.7 \pm 0.2^{\circ} \mathrm{C}$ for No. 28. Because semidiurnal fluctuations in $p$ and $T$ are biased by the $8 \mathrm{~h}$ sampling scheme, we show low passed data. The eliminated peak-to-peak short term variations were of $\mathrm{O}\left(18 \mathrm{dbar}, 0.15^{\circ} \mathrm{C}\right)$ with spuriously higher values for float No. 28.

\section{Analysis and discussion}

Since only one out of three sound sources of the RAFOS system was active during the SONNE experiment, some assumptions had to be made to convert the observed scalar distances into estimated trajectories. The first assumption we have made is that the upper core of the undercurrent system follows the bathymetry (Zenk and Armi, 1990). Particularly, this means that the undercurrent stays at a constant depth and does not slide up or down bathymetric obstacles such as the Tejo Plateau. Second, the cyclic flow in the southeastern corner of the Tejo Plateau, as shown by our floats during the first three weeks, is within a meddy. Third, different observation techniques and numerical models consistently have shown anticyclonic rotation in meddies. We therefore assume that the flow in the southeastern corner of the Tejo Plateau represents no exception from this rule.

Under these assumptions we have constructed estimates of trajectories for floats No. 20 and 28 (Figure 2). Both floats were launched approximately $14 \mathrm{~km}$ west of the 1000 fathoms $(1850 \mathrm{~m})$ isoline of the continental slope (Laughton et al.,1975). In the case of No. 28, some ambiguities at the end of the time series have been excluded by the knowledge of the surface point, S, obtained independently from the ARGOS positioning system.

Technical difficulties onboard FS SONNE prevented us from obtaining CTD records from either launch site. Nevertheless, both floats sank through the main thermocline right into a rotating water mass. No. 28 was ballasted for a target depth of about $600 \mathrm{~m}$. On the average this float drifted at $629 \mathrm{dbar}$ where, in this region, we encounter the top of the upper maximum of temperature and salinity in the Mediterranean outflow (cf. Sta. 11 in Zenk et al., 1989). The mean temperature of $11.7^{\circ} \mathrm{C}$ is also consistent with earlier observations in the undercurrent north of the Tejo Plateau. No. 20 was ballasted for $850 \mathrm{~m}$. Its average pressure and temperature were $847 \mathrm{dbar}$ and $12.1^{\circ} \mathrm{C}$, respectively.

For the first 16 days both floats, originally separated by $\sim 11 \mathrm{~km}$ in the horizontal and $\sim 218 \mathrm{~m}$ in the vertical, show considerable similarities in their rotation parameters (Table 1). They both recorded loops with azimuthal speeds $\left(v_{a}\right)$ of $>25 \mathrm{~cm} \mathrm{~s}^{-1}$ superimposed on a northwestward translation $\left(v_{t}\right)$ of $\sim 4 \mathrm{~cm} \mathrm{~s}^{-1}$. For the first seven days the shallower float, No. 28 , shows a steady temperature increase of $0.4^{\circ} \mathrm{C}$, which may be caused by absorption into the warm meddy core. No. 20 recorded five consecutive loops before leaving the meddy and returning in colder water southward, outside of the warm undercurrent. During the final seven days we see the return of No. 20 to the southeast without major oscillations in $d$ with a speed of about $8 \mathrm{~cm} \mathrm{~s}$ 1. At the beginning of this last period, the temperature drops by $0.4{ }^{\circ} \mathrm{C}$. Presumably, the float was transported by colder North Atlantic Central Water from this point on.

During the first 25 days the two trajectories are very similar. However, when float No. 20 reverses its direction, float No. 28 stops looping, and continues farther north. After day 354 this float exhibits a constant distance $d$. In order to reach the surface position $\mathrm{S}$ it has to migrate northeastward with an average speed of $\sim 10 \mathrm{~cm} \mathrm{~s}^{-1}$. Towards its end, No. 28 recorded substantially lower $\left(0.6^{\circ} \mathrm{C}\right)$ temperatures, which are characteristic for the level of Mediterranean Water north of the Plateau (Zenk et al., 1989).
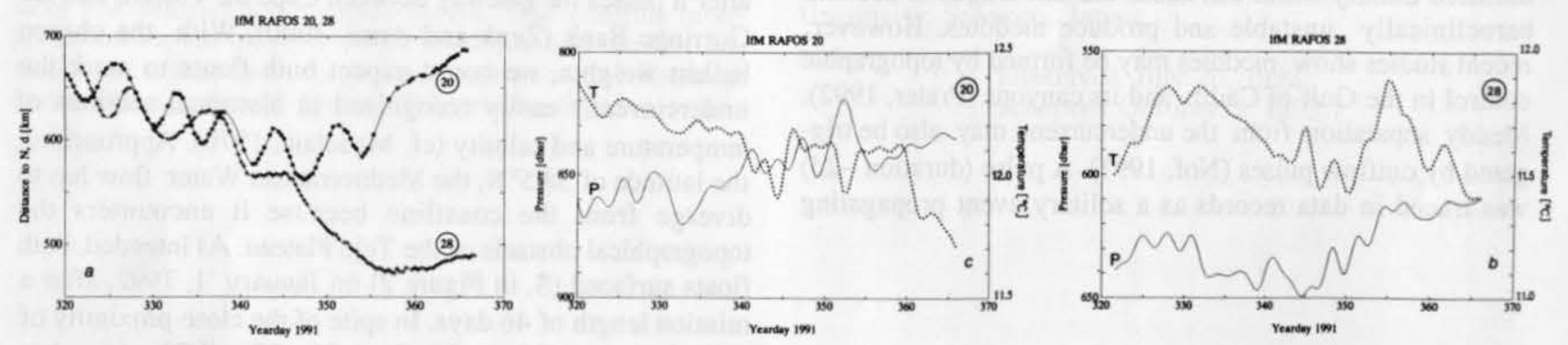

Fig. 1 (a) Time series of distance to sound source $\mathrm{N}$ for RAFOS floats No. 20 and 28 . The oscillations are interpreted as float rotations in the SONNE meddy. (b) Lowpass-filtered time series of pressure (p) and temperature (T) of float No. 28 and (c) of float No. 20. 


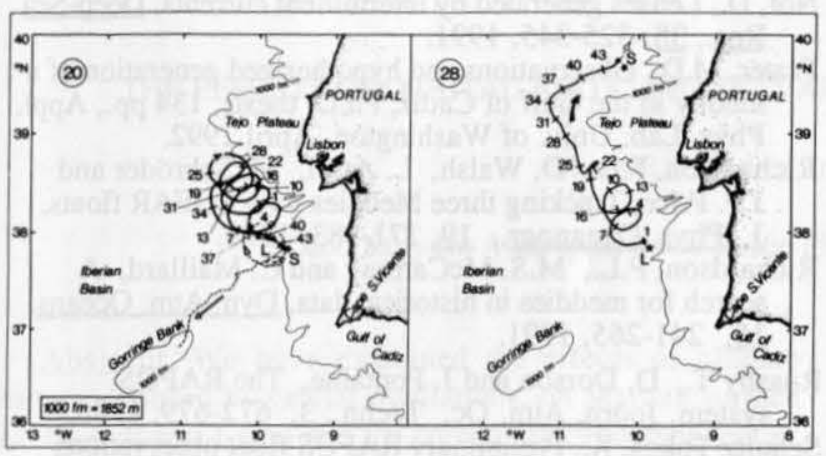

Fig. 2 Trajectories of float No. 20 (left) and 28. The 1000fathom $(1852 \mathrm{~m})$ isobath was adopted from Laughton et al., 1975. We have added the initial surface traces of the drifting floats (dashed lines) after they finished their underwater mission. Note that No. 20 performed a full anticyclonic loop right after surfacing. Originally both floats were captured in the SONNE meddy. Later they both left this vortex. No. 28 followed the bottom contours around the Tejo Plateau. Numbers denote 3 day intervals. To obtain yearday 1991, add 320.

Table 1. Typical meddy scales as derived from RAFOS float trajectories seen in Figure 2.

\begin{tabular}{llllccc}
\hline $\begin{array}{l}\text { Float } \\
\text { No }\end{array}$ & $\begin{array}{c}\text { Day No. } \\
\text { in 1991 }\end{array}$ & $\begin{array}{l}\text { No. of } \\
\text { loops }\end{array}$ & $\begin{array}{c}\varnothing \\
(\mathrm{km})\end{array}$ & $\begin{array}{c}\text { Period } \\
(\mathrm{d})\end{array}$ & $\begin{array}{c}v_{\mathrm{a}} \\
\left(\mathrm{cm} \mathrm{s}^{-1}\right)\end{array}$ & $\begin{array}{c}v_{\mathrm{t}} \\
\left(\mathrm{cm} \mathrm{s}^{-1}\right)\end{array}$ \\
\hline 20 & $320-347$ & 4 & 55 & 6 & 33 & 3.7 \\
28 & $321-336$ & 2.5 & 45 & 6.4 & 26 & 4.6 \\
\hline
\end{tabular}

\section{Concluding remarks}

So far, no direct observations of the generation of meddies have come to our knowledge. Actually, two analyses of historical data sets (Belkin and Kostianoi, 1988; Richardson et al., 1991) show a low concentration of meddies in the Iberian Basin. Numerical models (Beckmann and Käse, 1989) demonstrate that meddy formation often is associated with the appearance of partner eddies (dipoles, quadripoles) which, in addition to the background field, contribute significantly to the complexity of the Mediterranean Water dispersion on mesoscales. This fact may also be the reason for the lower meddy population in the Iberian Basin in the mentioned large scale studies of historical data, whose selection criteria may have failed under the sparse data coverage and due to the strong heterogeneity of water masses at middepth. Nevertheless, during recent years the existence of such features in the Iberian Basin have been proven unequivocally by hydrographic (Käse et al., 1989), Eulerian (Stammer et al., 1991) and Lagrangian (Schultz Tokos, 1992) current measurements, and tracer observations (Hinrichsen et al., 1992).

Our Lagrangian observations directly show the continuity of the Mediterranean Water path around the Tejo Plateau and the simultaneous existence of distance $(d)$ oscillations relative to point $\mathrm{N}$, several hundred kilometers towards the northwest. We interpret these sinusoidal spatial variations as meddy imprints on the slope of the southeast corner of the Plateau, where such vortices were not observed by any direct method before. A possible interpretation of the initial rotation of both floats is that they were captured in a juvenile meddy and were subsequently expelled from its warm core as the meddy encountered the Tejo Plateau. This SONNE meddy might have been generated in the canyon-rich continental slope farther south towards Cape St. Vincent. The behaviour of the floats around yearday 346 can either be interpreted as the decay of the meddy or more likely the deflection of the meddy to the west into the Iberian Basin, incidentally leaving the floats behind. The different behaviour of floats No. 20 and 28 at day 346 might be due to the ellipsoidal cross section of meddies. Float No. 28, being at a shallower depth might be expelled earlier than No. 20 since the radius of a lens-shaped meddy at this depth $(\sim 640 \mathrm{~m})$ would be less than at $\sim 850 \mathrm{~m}$. Temperature drops, seen in both floats, when they stop looping, support this scenario.

Before recovery both floats were tracked at the surface by ARGOS during calm weather conditions for over four weeks. No. 28 roughly followed a northerly course. Its drift is consistent with earlier observations by Frouin et al. (1990), who report a persistent poleward surface current parallel to the Iberian Peninsula during wintertime. Perhaps more interesting, No. 20 performed a complete anticyclonic loop at the surface (Figure 2). The circle diameter $(\varnothing \sim 50 \mathrm{~km})$ is comparable to the underwater loop diameter observed at the beginning of the mission. However, the rotation period is significantly longer $(\sim 10 \mathrm{~d})$. A similar vertical structure found at $38^{\circ} \mathrm{N} 13^{\circ} \mathrm{W}$ has also been recently observed in an independent meddy study (Schultz Tokos, 1992).

After one cycle at the sea surface, No. 20 leaves the circle and drifts towards the southwest. Since this anticyclonic trajectory appears exactly in the critical region southwest of the Tejo mouth (cf. L in Figure 2), it is tempting to interpret it as the surface expression of another newly arrived middepth vortex. This new meddy from January 1992, would then replace its predecessor from November, 1991, which was advected into the deep Iberian Basin triggered by the topography. The six-week time interval between the proposed meddy appearances in this region is not inconsistent with previous estimates of meddy generation frequencies (Richardson et al., 1989) of up to 8 meddies per year. Further tests of our hypothesis are necessary. They are planned for an extended experiment on FS ALKOR in autumn 1992 that will combine a hydrographic survey, a numerical meddy model, and more float observations.

Acknowledgements. We thank R. Zahn-Knoll and $\mathrm{H}$. Kudraß for their help in launching the RAFOS floats on board FS SONNE. Special thanks go to Y. Camus, Brest, who managed to recover both floats after they finished their missions. Figures were carefully prepared by $\mathrm{C}$. Brückner. This work is part of the research project SFB 133, supported by the Deutsche Forschungsgemeinschaft, Bonn. 


\section{References}

Armi, L. and W. Zenk, Large lenses of highly saline Mediterranean Water, L. Phys. Oceanogr. 14, 15601576, 1984.

Beckmann, A. and R.H. Käse, Numerical simulation of the movement of a Mediterranean Water lens, Geophys. Res. Letters, 16, 65-68, 1989.

Belkin I.M. and A.G. Kostianoi, Lenses of Mediterranean Water in the North Atlantic, in Hydrographical investigations in the "Mesopolygon" experiment, edited by V. G. Kort, Moscow, pp. 110-123 (in Russian), Nauka, 1988.

Frouin, R., A.F.G. Fiúza, I. Ambar and T.J. Boyd, Observations of a poleward surface current off the coasts of Portugal and Spain during winter, L. Geophys. Res., 25 , C1, 679-691, 1990.

Gründlingh, M.L., On the observation of a solitary event in the Mediterranean outflow west of Gibraltar, "Meteor" Forsch.-Ergebn., A/B, 12, 14-46, 1981.

Hinrichsen, H.-H., M. Rhein, R.H. Käse and W. Zenk, The Mediterranean Water tongue and its chlorofluoromethanes signal in the Iberian Basin in early summer 1989., J. Geophys. Res. (in press), 1992.

Käse, R.H. and W. Zenk, Reconstructed Mediterranean salt lens trajectories, L. Phys. Oceanegr., 17 158-163, 1987.

Käse, R.H., A. Beckmann and H.-H. Hinrichsen, Observational evidence of salt lens formation in the Iberian Basin, L. Geophys. Res., 94, C4, 4905-4912, 1989.

König, H. and W. Zenk, Principles of RAFOS technology at the Institut für Meereskunde Kiel, Ber. Inst. Meeresk. Kiel, 222, 99 pp., 1992.

Laughton, A.S., D.G. Roberts and R. Graves, Bathymetry of the Northeast Atlantic, scale 1:2, 400,000, Sheet 3, Inst. Oc. Sc., Wormley, UK, ca. 1975.

Madelain, F., Circulation des eaux d'origine méditerranéenne au niveau du Cap Saint-Vincent. Hydrologie et courants de densite, Rapport scientifiques et techniques CNEXO, 24, 74 pp., 1976.

McDowell, S.E., and H.T. Rossby, Mediterranean Water: An intense mesoscale eddy off the Bahamas, Science, $\underline{202}, 1085-1087,1978$.
Nof, D., Lenses generated by intermittent currents, Deep-Sea Res., 38, 325-345, 1991.

Prater, M.D., Observations and hypothesized generation of a meddy in the Gulf of Cadiz, Ph.D. thesis, 134 pp., Appl. Phys. Lab. Univ. of Washington, April 1992.

Richardson, P.L., D. Walsh, L. Armi, M. Schröder and J.F. Price, Tracking three Meddies with SOFAR floats, L. Phys, Oceanogr., 19, 371-383, 1989.

Richardson, P.L., M.S. McCartney and C. Maillard, A search for meddies in historical data, Dyn. Atm. Oceans, 15. 241-265, 1991.

Rossby T., D. Dorson and J. Fontaine, The RAFOS system, Journ. Atm. Oc. Techn., 3, 672-679, 1986.

Schultz Tokos, K., Preliminary RAFOS float observations from meddy ASKA, in Outflows and overflows in the Atlantic and their role in the eastern boundary current system. compiled by Ambar, I., L. Armi, M.O. Baringer, A. Bower, A. Fiúza, G.C. Johnson, R. Käse, M. Kennelly, E. Kunze, R. Lueck, P. Lundberg, C.G. Martins, M.D. Prater, J. Price, M. Rhein, T. Sanford, K. Tokos, J. Verrall, and W. Zenk, Proc. Int. Workshop, Univ. Lisbon, 36-40, 1992.

Stammer D., H-H Hinrichsen, and R.H. Käse, Can Meddies be detected by satellite altimetry? L. Geophys. Res., 96, C4, 7005-7014, 1991.

Zenk, W., T.J. Müller, and G.Wefer, BARLAVENTOExpedition, Reise Nr. 9, 29. Dez. 1988 - 17. März 1989. METEOR-Berichte. Univ. Hbg., 89-2, 238 pp, 1989.

Zenk, W. and L. Armi, The complex spreading pattern of Mediterranean Water off the Portuguese continental slope, Deep-Sea Res., 37, 1805-1823, 1990.

W. Zenk, K. Schultz Tokos, and O. Boebel, Institut für Meereskunde an der Universität Kiel, 2300 Kiel 1, Germany

Received July 17, 1992; revised August 31, 1992; accepted September 9, 1992. 